\title{
Hifdz Al-Maal dalam Regulasi Rahasia Perbankan
}

\author{
Luqman Nurhisam1, Dimas Aprilianto ${ }^{2}$ \\ IAIN Kudus', IAIN Kudus ${ }^{2}$ \\ luqman@iainkudus.ac.id1', apriliantodimas19@gmail.com ${ }^{2}$
}

\begin{abstract}
Bank secrecy refer to secrets in the relationship between a bank and a customer. In accordance with Article 40 paragraph (1) of Law Number 10 Year 1998 concerning Banking, it is stated that banks are required to keep confidential information regarding their depositing customers and their deposits. The research was conducted using the library research method, which looks for normative sources of law by reviewing the laws and regulations that apply or are applied to a particular legal problem. The approach used is the statutory approach, namely the approach taken by examining laws relating to bank secrecy. The purpose of this study is to further examine how Islamic law views the regulation of bank secrecy in Indonesia. The results of this study are related to the maintenance of one of the basic needs elements, namely assets that must be protected (hifdz al-maal), so if other parties ask for an explanation of the financial condition of a customer from a bank, this is not allowed.
\end{abstract}

Keywords: bank secrecy, hifdz al-maal

\begin{abstract}
Abstrak
Rahasia bank mengacu pada rahasia dalam hubungannya antara bank dan nasabah. Sesuai pasal 40 ayat (1) Undang-Undang Nomor 10 Tahun 1998 Tentang Perbankan menegaskan bahwa bank wajib merahasiakan keterangan mengenai nasabah penyimpan dan simpanannya. Penelitian dilakukan dengan menggunakan metode penelitian pustaka, yang mana mencari sumber hukum normatif dengan cara mengkaji peraturan perundang-undangan yang berlaku atau diterapkan terhadap suatu permasalahan hukum tertentu. Pendekatan yang dipakai adalah pendekatan Undang-Undang yaitu pendekatan yang dilakukan dengan cara menelaah Undang-Undang yang berhubungan dengan rahasia bank. Tujuan penelitian ini adalah untuk mengkaji lebih lanjut mengenai bagaimana pandangan hukum Islam terhadap pengaturan rahasia bank di Indonesia. Hasil daripada penelitian ini sehubungan dengan pemeliharaan salah satu unsur kebutuhan pokok yaitu harta yang harus dilindungi (hifdz al-maal), maka apabila ada pihak-pihak lain meminta penjelasan mengenai keadaan keuangan suatu nasabah dari suatu bank, maka hal tersebut tidak diperbolehkan.

Kata Kunci: rahasia bank, hifdz al-maal
\end{abstract}

\section{PENDAHULUAN}

Salah satu faktor yang dapat mempengaruhi kadar kepercayaan masyarakat kepada bank adalah terjamin atau tidaknya rahasia nasabah yang ada di bank. Data nasabah yang ada di bank, baik data keuangan maupun non-keuangan, merupakan suatu data yang tidak ingin diketahui oleh orang lain atau pihak lain. Bila kerahasiaan data nasabah tidak dapat dijamin oleh bank, maka nasabah akan merasa enggan untuk 
berhubungan dengan bank. Pada umumnya sekitar 90\% (sembilan puluh persen) dana yang diputar berasal dari masyarakat dan hanya sebagian kecil yang berasal dari modal sendiri bank (Husein, 2010:79).

Masyarakat sebagai nasabah bank yang mempercayakan dana mereka untuk dikelola oleh bank juga harus mendapatkan perlindungan terhadap tindakan yang dilakukan pihak perbankan yang dapat mendatangkan kerugian. Selain itu demi menjaga nama baik nasabah serta simpanan nasabah, harus diatur kapan serta dalam hal yang bagaimana bank baru dapat diperkenankan untuk memberitahukan pada pihak ketiga segala sesuatu yang berhubungan dengan keuangan dan halhal lain dari nasabah yang diketahui oleh bank karena kegiatan usahanya. Masyarakat hanya akan memanfaatkan jasa-jasa bank apabila dari bank ada jaminan bahwa bank tidak akan menyalahgunakan pengetahuannya tentang simpanan dan keadaan keuangan dari nasabahnya. Oleh karena itu nasabah bank sebagai konsumen perbankan patut dilindungi hak dan kepentingannya (Santosa, 2011:113).

Orang yang menyimpan dananya di bank, selain menghendaki uangnya aman, juga tidak ingin simpanannya diketahui oleh orang lain. Begitu pula dalam hal nasabah memperoleh kredit, bank tidak perlu memberitahu kepada pihak ketiga. Jadi pada pokoknya nasabah dalam berhubungan dengan bank, menghendaki adanya jaminan kerahasiaan keuangan dari bank supaya tidak terjadi penyalahgunaan. Dilain pihak bank juga tidak ingin kepercayaan yang diberikan masyarakat menjadi luntur. Oleh karena itu untuk menghindari hubungan yang tidak baik antara bank dengan nasabahnya, dalam Undang-Undang Perbankan 1992 diatur tentang ketentuan Rahasia Bank (Supramono, 1996:18). Timbulnya pemikiran untuk perlunya merahasiakan keadaan keuangan nasabah bank sehingga melahirkan ketentuan hukum mengenai kewajiban Rahasia Bank semula bertujuan untuk melindungi kepentingan nasabah secara individual.

\section{KAJIAN LITERATUR}

Hubungan antara bank dan nasabah lebih ditekankan pada kewajiban bagi bank agar tidak membuka kerahasiaan data dari nasabahnya kepada pihak ketiga ataupun pihak lain, kecuali ditentukan lain oleh Undang-Undang yang berlaku. Hal inilah yang disebut Rahasia Bank, bahwa Rahasia Bank mengacu pada rahasia dalam hubungannya antara bank dan nasabah. Sesuai Pasal 1 angka 28 Undang-Undang Nomor 10 Tahun 1998 Tentang Perbankan menegaskan bahwa, Rahasia Bank adalah segala sesuatu yang berhubungan dengan keterangan mengenai nasabah penyimpan dan simpanannya. Pasal 1 angka 16 Undang-Undang Nomor 7 Tahun 1992 tentang Perbankan menegaskan bahwa, Rahasia Bank adalah segala sesuatu yang berhubungan dengan 
keuangan dan hal-hal lain dari nasabah bank yang menurut kelaziman dunia Perbankan wajib dirahasiakan.

Hal tersebut diatur dengan pengaturan Rahasia Bank di dalam Pasal 40 ayat (1) Undang-Undang Perbankan menegaskan bahwa, Bank wajib merahasiakan keterangan mengenai nasabah penyimpan dan simpanannya, kecuali dalam hal sebagaimana dimaksud dalam Pasal 41, Pasal 41 A, Pasal 42, Pasal 43, Pasal 44, dan Pasal 44 A. Upaya yang dilakukan pemerintah dalam lembaga perbankan khususnya pada bank dengan melakukan pengecualian pada kerahasiaan bank yaitu ketentuan kerahasiaan bank bukan mutlak akan tetapi bukan tak terbatas karena adanya beberapa pengecualian pada kerahasiaan bank itu sendiri sehingga, untuk kepentingan tertentu bisa untuk dibuka dan diketahui. Beberapa pengecualian dalam Rahasia Bank (Sutedi, 2007:9) tersebut adalah:

1. Untuk kepentingan perpajakan

2. Penyelesaian piutang bank yang sudah diserahkan kepada Badan Urusan Piutang dan Lelang Negara atau Panitia Urusan Piutang Negara.

3. Kepentingan peradilan dalam perkara pidana

4. Kepentingan peradilan dalam perkara perdata antara bank dengan nasabahnya

5. Tukar-menukar informasi antar bank

6. Permintaan, persetujuan atau kuasa dari nasabah penyimpan yang dibuat secara tertulis

7. Permintaan ahli waris yang sah dari nasabah penyimpan yang telah meninggal dunia.

Ketentuan tentang Rahasia Bank diatur pula dalam Undang-Undang Nomor 23 Tahun 1999 tentang Bank Indonesia dan Peraturan Bank Indonesia Nomor 2/19/PBI/2000 tentang persyaratan dan Tata Cara Pemberian Perintah atau Izin Tertulis Membuka Rahasia Bank. Sesungguhnya demikian, dengan adanya ketentuan tentang Rahasia Bank, dimana bank dilarang mengungkapkan data-data rekening dan berbagi keterangan personal dari para nasabahnya, tidak berarti bahwa bank akan terbebas dari masalah. Masalah yang kemungkinan timbul adalah adanya pertentangan kepentingan antara kepentingan individu dengan kepentingan umum. Bank sangat berkepentingan untuk menjaga dan memelihara kepercayaan nasabah dengan cara merahasiakan segala sesuatu tentang nasabah dan simpanannya. Namun disisi lain, terdapat pula kepentingan pihak-pihak lain, seperti kepolisian dan kejaksaan, yang mempunyai kewenangan di bidang penyidikan atau penuntutan, sehingga hal tersebut telah menimbulkan perbedaan persepsi di dalam menafsirkan ketentuan Rahasia Bank. Maka, berdasarkan hal tersebut, peneliti mencoba mengkaji dan menganalisa lebih lanjut terkait konsep 
pengaturan rahasia perbankan di Indonesia dengan menggunakan tinjauan Hukum Islam.

\section{METODE PENELITIAN}

Jenis penelitian yang digunakan yakni kualitatif. Metode penelitian yang digunakan dalam penelitian ini yakni menggunakan kajian pustaka yang merupakan dengan menggunakan dalil al-Qur'an, hadist, buku, artikel jurnal, internet dan pendapat dari ahli dalam bidang terkait yang sesuai dengan pembahasan. Penelitian ini meneliti lebih mendalam Pasal 1 angka 28 Undang-Undang Nomor 10 Tahun 1998 Tentang Perbankan.

\section{PEMBAHASAN}

Tujuan daripada diturunkannya syariat Islam adalah untuk kebaikan seluruh umat manusia. Di dalam ruang lingkup ushul fikih tujuan ini disebut dengan maqashid as-syari'ah sebagaimana dimaknai dengan maksud dan tujuan diturunkannya syariat Islam. Kaitannya dengan maqashid as-syari'ah, terdapat 3 jenis maslahah yang ada dalam hukum Islam, yaitu maslahah daruriyyat (primer), maslahah hajiyyat (sekunder), dan maslahah tahsiniyyat (tersier). Adapun maslahah yang berkaitan dengan harta benda seseorang yaitu maslahah daruriyyat. Maslahah daruriyyat dimaksudkan untuk memelihara lima unsur pokok yang esensial, merupakan tujuan mutlak yang harus ada, sehingga kalau tujuan ini tidak ada, maka akan berakibat fatal karena terjadinya kehancuran dan kekacauan secara menyeluruh.

Menurut Asy-Syatibi, maslahah daruriyyat disebut juga dengan maslahah haqiqiyyah yang mana dimaknai maslahah yang keberadaannya berhubungan langsung dengan kebutuhan esensi (pokok) manusia (Asy-Syatibi: 1996:8), yaitu sesuatu yang berhubungan dengan pemeliharaan agama (hifdz al-din), jiwa (hifdz al-nafs), keturunan (hifdz alnasl), harta (hifdz al-maal) dan akal (hifdz al-'aql).

Islam mengharuskan orang mengetahui ilmu yang digunakan untuk mencari, melindungi, menggunakan, dan memelihara harta yang dimiliki. Manusia dilarang untuk hidup boros dan menghambur-hamburkan uang. Maka seharusnya setiap orang berusaha untuk menyimpan uangnya demi kebutuhan yang mendadak demi keadaan tertentu. Misalnya dengan memanfaatkan adanya fasilitas bank untuk menyimpan harta seperti uang. Dengan demikian, kehadiran bank sangat membantu pemilik uang dari banyak kemungkinan yang akan mengganggu yang akan dihadapi seperti adanya baik perampok, maling maupun bahaya-bahaya lainnya seperti bencana seperti kebakaran, banjir, gempa dan lain-lain.

Bank merupakan lembaga keuangan yang eksistensinya tergantung mutlak pada kepercayaan dari para nasabahnya yang mempercayakan dana simpanan mereka pada bank. Oleh karena itu bank sangat 
berkepentingan agar tingkat kepercayaan masyarakat, yang telah maupun yang akan menyimpan dananya, terpelihara dengan baik dalam tingkat yang tinggi. Mengingat bank adalah bagian dari sistem keuangan dan sistem pembayaran, yang masyarakat luas berkepentingan atas kesehatan dari sistem-sistem tersebut, sedangkan kepercayaan masyarakat kepada bank merupakan unsur paling pokok dari eksistensi suatu bank, maka terpeliharanya kepercayaan masyarakat kepada perbankan adalah juga kepentingan masyarakat banyak.

Ada beberapa faktor yang sangat mempengaruhi tingkat kepercayaan masyarakat terhadap suatu bank. Faktor-faktor tersebut adalah:

1. Integritas dalam kepengurusan

2. Pengetahuan dan kemampuan pengurus baik berupa pengetahuan kemampuan manajerial maupun pengetahuan dan kemampuan teknis perbankan

3. Kesehatan bank yang bersangkutan

4. Kepatuhan bank terhadap kewajiban rahasia bank.

Untuk dapat memelihara dan meningkatkan kepercayaan masyarakat terhadap suatu bank pada khususnya dan perbankan pada umumnya adalah kepatuhan bank terhadap kewajiban rahasia bank. Maksudnya adalah menyangkut "dapat atau tidaknya bank dipercaya oleh nasabah yang menyimpan dananya pada bank tersebut untuk tidak mengungkapkan simpanan nasabah identitas nasabah tersebut kepada pihak lain".

Ada anggapan dari sebagian orang bahwa kerahasiaan bank bisa merugikan masyarakat, ketika ada nasabah nakal bisa berlindung pada ketentuan rahasia bank, kerahasiaan bank harus dibuka untuk kepentingan para penitip dana dan sebagainya. Sedangkan di pihak lain menghendaki dan menegaskan bahwa bank harus memegang teguh rahasia bank karena masyarakat hanya akan mempercayakan uangnya pada bank atau memanfaatkan jasa bank apabila dari pihak bank ada jaminan bahwa pengetahuan bank tentang simpanan dan keadaan keuangan nasabah tidak akan disalahgunakan.

Beberapa perbedaan tersebut selalu menjadi isu mengenai apakah yang perlu dilindungi hanya kepentingan nasabah yang bersangkutan secara individual, ataukah terkait juga kepentingan-kepentingan bank serta kepentingan masyarakat umum berkaitan dengan berlakunya ketentuan rahasia bank di masing-masing negara. Selain itu, yang menjadi isu sampai sejauh mana kepentingan nasabah yang bersangkutan wajib dilindungi dalam hal perlunya diungkapkan keterangan mengenai simpanan dan nasabah penyimpan serta transaksi nasabah dengan bank yang bersangkutan. Apabila terjadi benturan-benturan antara kepentingan nasabah dan kepentingan umum, serta benturan antara kepentingan 
nasabah dan kepentingan bank, hal-hal tersebut telah diatur dalam ketentuan yang menyangkut pengecualian atas kewajiban bank untuk memegang teguh rahasia bank (Sjahdeini, 2005:4).

Perkembangan keadaan politik dalam negeri, keadaan sosial, terutama menyangkut timbulnya kejahatan-kejahatan di bidang pencucian uang, dan kebutuhan akan adanya stabilitas ekonomi, terutama stabilitas moneter. Hal tersebut telah menimbulkan kebutuhan akan perlunya pelonggaran terhadap kewajiban rahasia bank apabila kepentingan bangsa dan masyarakat umum didahulukan daripada kepentingan nasabah bank. Sebaliknya, dalam hal-hal tertentu untuk kepentingan negara, bangsa, dan masyarakat umum kewajiban rahasia bank diperketat, dengan alasan pertimbangan demi berhasilnya pengerahan tabungan masyarakat oleh perbankan dan terjaminnya stabilitas moneter yang dapat terganggu jika kepercayaan masyarakat terhadap perbankan runtuh (Sjahdeini, 2005:11).

Para pakar hukum yang berpendapat bahwa "kepentingan umum" (public interest) merupakan "alasan pembenar" bagi pelanggaran ketentuan rahasia bank oleh bank. penulis sependapat bahwa "alasan demi kepentingan umum" menghilangkan sifat melawan hukum dari tindak pidana rahasia bank tersebut.

Apabila regulasi seperti Undang-Undang menetapkan unsur atau unsur-unsur apa saja yang harus dipenuhi agar dapat ditentukan bahwa dalam suatu kasus terdapat "kepentingan umum". Mengingat demikian banyak Undang-Undang menyebut "kepentingan umum" sebagai alasan pembenar, misalnya dalam hal kejaksaan menggugat mewakili kepentingan umum atau demi kepentingan umum, atau kejaksaan mengajukan permohonan pailit terhadap seorang debitur dengan alasan demi kepentingan umum, maka sebaiknya unsur atau unsur-unsur sebagaimana yang saya maksudkan itu dapat ditentukan tidak hanya terbatas berlaku dalam hal rahasia bank saja, tetapi juga dapat diberlakukan dalam hal-hal yang lain.

Menjaga rahasia hukum asalnya adalah wajib karena rahasia termasuk janji yang harus ditunaikan. Sebagaimana dalam firman Allah Swt. (QS. Al-Isra' (17), 34):

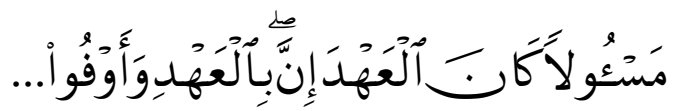

Termasuk yang perlu diteladani dalam penjagaan rahasia adalah penjagaan para sahabat terhadap rahasia Nabi Muhammad Saw. Dari Tsabit, dari Anas ra., beliau berkata (Shahih Muslim, 1981:41) :

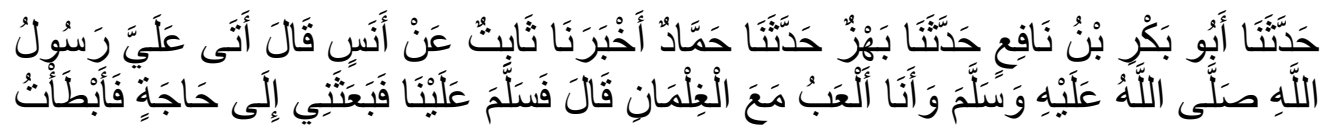




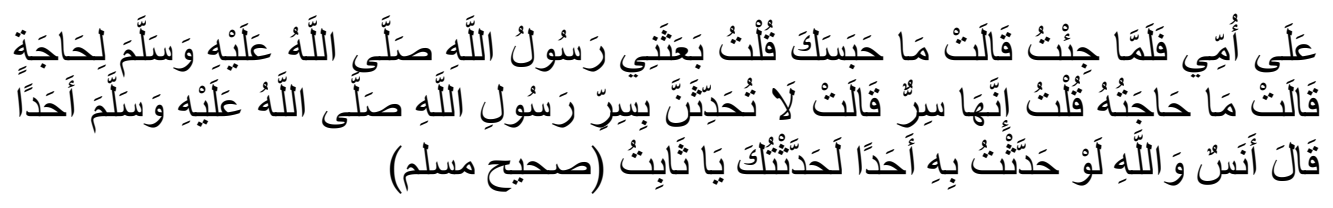

Seorang muslim harus pandai dalam menjaga rahasia, penuh amanat apabila diberi titipan, dan penuh tanggung jawab terhadap keselamatan sesama saudara seiman. Bahkan, dalam memegang rahasia, setiap pribadi muslim benar-benar menjaga amanat tersebut. Karena teguhnya memegang suatu rahasia maka ia langsung "mengubur" amanat tersebut dan tidak pernah sedikit pun terbongkar. Selanjutnya dalam sabda Rasulullah Saw. (Shahih Muslim, 1981:143):

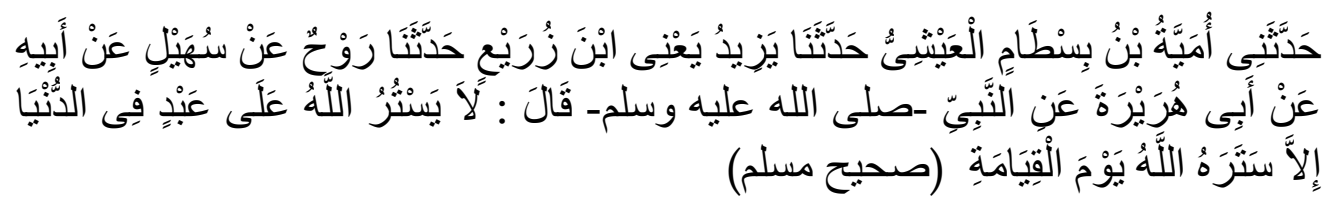

Secara umum, tujuan utama hukum adalah mewujudkan maslahah untuk kehidupan manusia seluruhnya, maka dapat dikatakan bahwa penetapan hukum sangat berkaitan dengan dinamika kemaslahatan yang berkembang dalam masyarakat, baik kemaslahatan di dunia maupun kemaslahatan di akhirat.

Musthafa Syalabi menegaskan bahwa adanya perubahan hukum adalah karena perubahan maslahat (tabaddul al-ahkam bi tabaddul almaslahah) dalam masyarakat. Adanya an-nasakh (penghapusan suatu hukum terdahulu dengan hukum yang baru), at-tadarruj fi at-tasyri' (pentahapan dalam penetapan hukum) dan nuzuul al-ahkam yang selalu mengikuti peristiwa-peristiwa yang terjadi pada masa pewahyuan, semuanya merupakan dalil yang jelas menunjukkan bahwa perubahan hukum mengikuti perkembangan meliputi perubahan maslahat yang ada (Syalabi, 1981:307).

Di sisi lain, tegaknya hukum yang adil yang menjamin kepastian hukum yang mana merupakan kebutuhan baik sebagai individu, bangsa dan negara. Penegakan hukum yang baik bukan saja diperlukan untuk perlindungan masyarakat, tetapi juga diperlukan untuk menciptakan iklim yang kondusif bagi investor baik dari dalam maupun luar negeri. Dalam penegakan hukum seringkali dibutuhkan informasi dan alat bukti berupa keterangan tentang keadaan keuangan seseorang atau pelaku tindak pidana. Dengan kata lain terdapat juga kepentingan umum untuk membuka rahasia bank tersebut, misalnya untuk pemberantasan tindak pidana yang hasilnya seringkali disimpan di bank dalam artian tindakan pencucian uang (money laundry). Terlebih lagi pada dewasa ini penegakan hukum dilakukan juga dengan pendekatan mengejar hasil 
tindak pidana. Pendekatan tersebut perlu dilakukan dengan beberapa alasan yaitu:

1) Untuk mengurangi motivasi manusia sebagai homo economicus untuk melakukan tindak pidana.

2) Jangkauannya lebih jauh dan lebih adil karena dapat menjangkau pelaku yang ada "di belakang layar".

3) Untuk memaksimalkan recovery aset hasil dari tindak pidana.

4) Pendekatan ini relatif lebih mudah karena tidak banyak mendapat resistensi.

Dengan demikian terdapat dua kepentingan umum yang bertemu, yaitu kepentingan nasabah dan industri perbankan dan kepentingan penegakan hukum. Mengingat kepentingan penegakan hukum diperlukan oleh semua pihak dan lebih besar dibandingkan dengan kepentingan perlindungan terhadap nasabah perorangan, maka ketentuan rahasia bank dapat diterobos untuk kepentingan penegakan hukum.

Hukum Islam memberikan rambu-rambu bahwa harta dapat dijadikan sebagai alat untuk mendekatkan diri kepada Allah Swt., sebagaimana dalam firman-Nya (QS. Al-Mujadalah (58), 17):

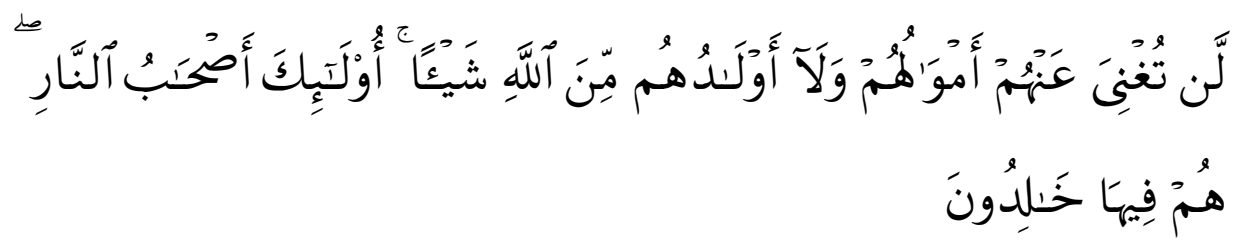

Ayat di atas memberikan inspirasi bahwa hakikat kehidupan di dunia ini adalah melaksanakan ibadah kepada Allah Swt. dan mencari ridha-Nya, termasuk dalam persoalan harta. Dimana pemeliharaan harta di bank sebagai wujud kepercayaan nasabah terhadap bank.

Segala ketentuan hukum yang telah ditetapkan oleh Allah Swt. harus mempunyai alasan-alasan tertentu dan mengandung hikmah, 'illah, dan maslahah yang hendak dicapai. Sebab jika tidak demikian, maka ketentuan-ketentuan hukum yang telah ditetapkan oleh Allah Swt. itu tidak ada gunanya dan hal ini tentu tidak boleh terjadi.

Peneliti memiliki pandangan bahwasanya suatu hal yang ideal di dalam pengaturan regulasi ketentuan rahasia bank adalah bagaimana mencapai keseimbangan antara kepentingan pribadi nasabah, kepentingan perbankan di satu sisi dengan kepentingan penegakan hukum di sisi lain. Dengan kata lain, yang terpenting adalah bagaimana menciptakan adanya keseimbangan antara kedua kepentingan tersebut. Keseimbangan tersebut bersifat dinamis, yang mana bisa berubah sesuai dengan perkembangan zaman. Hanya saja kecenderungan pada akhirakhir lebih berat kepada membuka ketentuan rahasia bank untuk 
kepentingan yang lebih besar, yaitu kepentingan maslahah secara komprehensif.

Apabila dipahami oleh umat Islam bahwa konsep maslahah sebagai inti dari maqasid asy-syari'ah,dapat dipahami bahwa maqasid asysyari'ah sebagai ruh dari hukum Islam, sedangkan mașlaḥah adalah sebagai tujuan dan cita-cita idela dari ajaran Islam secara teoritis. Oleh karena itu, konsep maslahah dianggap sebagai alternatif terbaik dalam pengembangan-pengembangan metode ijtihad, di mana al-Qur'an dan Sunnah harus dipahami melalui metode-metode ijtihad dengan memberikan penekanan pada dimensi maslahah, sehingga maslahah merupakan wahana bagi perubahan hukum (Hasan, 1994:153).

Hukum Islam yang dipahami sebagai hukum yang memiliki rangkap balasan menyediakan undang-undang (aturan-aturan tentang kehidupan) yang mengandung nilai-nilai moral dan akhlak bagi setiap individu yang diantaranya adalah berhubungan dengan masyarakat sosial, yang memberikan jaminan kebahagiaan kepada setiap Muslim pada khususnya dan kepada umat lain pada umumnya. Di mana yang harus dijunjung tinggi dalam kehidupan bermasyarakat adalah tanggung jawab bersama.

Inti daripada maqasid asy-syari'ah adalah kemaslahatan. Kemaslahatan dalam taklif tuhan dapat berwujud dua bentuk, yaitu: 1) dalam bentuk hakiki, yakni manfaat langsung dalam arti kausitas. 2) dalam bentuk majazi, yakni bentuk yang merupakan membawa kepada kemaslahatan.

Kemaslahatan menurut Asy-Syatibi dilihat dari dua sudut pandangan, yaitu: 1) maqasid al-syari' (tujuan Tuhan). 2) maqasid almukallaf (tujuan mukallaf). Maqasid asy-syari'ah dalam arti maqasid alsyari', mengandung 4 aspek (Asy-Syatibi: 1996:5), yakni:

1. Tujuan awal dari syariat yakni kemaslahatan manusia di dunia dan di akhirat.

Aspek ini berkaitan dengan muatan dan hakikat maqasid asy-syari'ah.

2. Syariat sebagai sesuatu yang harus dipahami.

Berkaitan dengan dimensi bahasa, agar syariat dapat dipahami sehingga dicapai kemaslahatan yang dikandungnya.

3. Syariat sebagai suatu hukum takhfif yang harus dilakukan.

Berkaitan dengan pelaksanaan ketentuan-ketentuan syariat dalam rangka mewujudkan kemaslahatan. Dan juga berkaitan dengan kemampuan manusia untuk melaksanakannya.

4. Tujuan syariat adalah membawa manusia ke bawah naungan hukum. Berkaitan dengan kepatuhan manusia sebagai mukallaf di bawah dan terhadap hukum-hukum Allah (aspek tujuan syariat berupaya membebaskan manusia dari kekangan hawa nafsu). 
Aspek kedua, ketiga dan keempat pada dasarnya lebih sebagai penunjang aspek pertama sebagai aspek inti, namun memiliki keterkaitan dan menjadi rincian dari aspek pertama. Dalam keterkaitan itulah tujuan diciptakannya syariat, yaitu kemaslahatan manusia di dunia dan akhirat, sebagai aspek inti, dapat diwujudkan(Asy-Syatibi: 1996:5).

Menurut imam Asy-Syatibi, Allah Swt. menurunkan syariat Islam adalah untuk mengambil kemaslahatan dan menghindari kemadaratan (jalbul mashalih wa dar'ul mafasid). Dengan bahasa yang lebih mudah, aturan-aturan hukum yang Allah tentukan hanyalah untuk kemaslahatan manusia itu sendiri. Asy-Syatibi, kemudian membagi maslahat ini kepada tiga bagian penting yaitu daruriyyat (primer), hajiyyat (sekunder) dan tahsiniyyat (tersier).

Adapun maslahah yang berkaitan dengan harta benda seseorang yaitu maslahah daruriyyat. Maslahah daruriyyat dimaksudkan untuk memelihara lima unsur pokok yang esensial, merupakan tujuan mutlak yang harus ada, sehingga kalau tujuan ini tidak ada, maka akan berakibat fatal karena terjadinya kehancuran dan kekacauan secara menyeluruh.

Maslahah daruriyyat adalah sesuatu yang mesti adanya demi terwujudnnya kemaslahatan agama dan dunia. Apabila hal ini tidak ada, maka akan menimbulkan kerusakan bahkan hilangnya hidup dan kehidupan seperti makan, minum, shalat, puasa dan ibadah-ibadah lainnya. Yang termasuk maslahah daruriyyat ada lima yakni pemeliharaan terhadap agama, jiwa, keturunan, harta dan akal(AsySyatibi: 1996:7).

Cara untuk menjaga yang lima tadi dapat ditempuh dengan dua cara yaitu, pertama, dari segi adanya (min nahiyyati al-wujud) yaitu dengan cara manjaga dan memelihara hal-hal yang dapat melanggengkan keberadaannya, dan kedua, dari segi tidak ada (min nahiyyati al-'adam) yaitu dengan cara mencegah hal-hal yang menyebabkan ketiadaannya. Memelihara harta pada peringkat utama daruriyyat, seperti disyariatkan tata cara kepemilikan melalui jual beli dan dilaranganya mengambil harta orang lain dengan cara tidak benar seperti mencuri. Apabila aturan ini dilanggar akan mengancam eksistensi harta tersebut.

Berkaitan dengan pemeliharaan salah satu unsur pokok yaitu harta benda (hifdz al-maal) yang mana jika ditinjau dari sisi hukum Islam, maka apabila ada pihak-pihak lain (selain yang telah ditentukan atau disebutkan sebagai pihak-pihak yang boleh pemperoleh pengecualian) yang meminta penjelasan mengenai keadaan keuangan suatu nasabah dari suatu bank, maka tidak diperbolehkan.

\section{KESIMPULAN}

Berkaitan dengan pemeliharaan salah satu unsur pokok yaitu harta (hifdz al-maal) yang mana jika ditinjau dari sisi hukum Islam, maka apabila 
ada pihak-pihak lain (selain yang telah ditentukan atau disebutkan sebagai pihak-pihak yang boleh pemperoleh pengecualian) yang meminta penjelasan mengenai keadaan keuangan suatu nasabah dari suatu bank, maka tidak diperbolehkan.

\section{DAFTAR PUSTAKA}

QS. Al-Isra' (17) : 32

QS. Al-Mujadalah (58) : 17

Asy-Syatibi. (1996). Al-Muwafaqat fi Usul al-Syari'ah, Jilid 2, Beirut: Dar alMa'rifah.

Az, Lukman Santosa. (2011). Hak dan Kewajiban Hukum Nasabah Bank, cet. ke-1, Jakarta: Pustaka Yustisia.

Hasan, Ahmad. (1994). Analogical Reasoning in Islamic Jurisprudence: a studi of the Juridical Apasrisiple of Qiyas, New Delhi: Adam Publishers and Distributors.

Husein, Yunus. (2010). Rahasia Bank dan Penegakan Hukum, Jakarta: Pustaka Juanda Tigalima.

Muslim, Shahih. (1981). Al-Birr was Silah wal Adab, Jilid 15, Beirut: Dar alFikr.

Muslim, Shahih. (1981). Fadailul A'mal ash-Sahabah, Jilid 16, Beirut: Dar al-Fikr.

Peraturan Bank Indonesia Nomor 2/19/PBI/ 2000.

Supramono, Gatot. (1996). Perbankan dan Masalah Kredit: Suatu Tinjauan Yuridis, Jakarta: Djambatan.

Sutan, Remy Sjahdeini. (2005). Perbankan Islam dan Kedudukannya dalam Tata Hukum Perbankan Indonesia, Jakarta: Pustaka Utama Grafiti.

Sutedi, Adrian. (2007). Hukum Perbankan Suatu Tinjauan Pencucian Uang, Merger, Likuidasi dan Kepailitan, Jakarta: Sinar Grafika.

Syalabi, Muhammad Mustafa. (1981). Ta'lil al-Ahkam, Beirut: Dar anNahdhah al-'Arabiyah.

Undang-Undang Nomor 7 Tahun 1992 tentang Perbankan

Undang-Undang Nomor 10 Tahun 1998 tentang Perbankan 
Halaman ini sengaja dikosongkan 